\title{
Combining Ability, Heritability and Gene Action Assessment in Rapeseed (Brassica napus L.) for Yield and Yield Attributes
}

\author{
Muhammad Ali Shah, Faiz Ur Rehman, Abbas Mehmood, Fareed Ullah, Sayed Irfan Shah and Syed Majid \\ Rasheed*
}

Department of Agriculture, Bacha Khan University Charsadda, Khyber Pakhtunkbwa, Pakistan.

Abstract | An F1 hybrid of Brassica napus L., derived from $5 \times 5$ diallel, was studied to estimate combining
ability, heritability and gene action of morphological and yield associated traits, utilizing randomized complete
block design (RCBD) with two replications, at Bacha Khan Agricultural Research Farm (BARF), Charsadda,
Khyber Pakhtunkhwa, Pakistan during the growing season of $2017-18$. The data were collected for pods
related traits and total yield. The results of the study showed significant differences among parents and F1's for
all the studied traits. General and specific combining ability analysis revealed non-significant results for the
traits under consideration, suggesting the involvement of non-additive type of gene action. A higher broad
sense heritability estimate was evident. It was concluded from the combining ability analysis of the present
study that genotype 2702 was best general as well as a specific combiner for pod length (PL), seeds pod ${ }^{-1}$
(SPP), total yield (TY), and 1000 seed weight (SW). In addition, maximum pod length, seeds pod ${ }^{-1}$, total
yield, 1000 seed weight and pods plant ${ }^{-1}$ (PPP) were observed for those F1 hybrids where genotype 2702 was
used as seed setter, i.e. $2702 \times$ P1-119 and $2702 \times$ DUNCLED. Higher broad-sense heritability and non-
additive type of genetic variability indicated that it could be integrated as a valuable tool in breeding strategies
to choose genotypes of B. napus L. for high yielding traits.
Received | December 13, 2019; Accepted | December 04, 2020; Published | February 06, 2021
"Correspondence | Syed Majid Rasheed,Department of Agriculture, Bacha Khan University Charsadda, Khyber Pakhtunkhwa, Pakistan; Email:
smrasheed@bkuc.edu.pk
Citation | Shah, M.A., F.U. Rehman, A. Mehmood, F. Ullah, S.I. Shah and S.M. Rasheed. 2021. Combining ability, heritability and gene action
assessment in rapeseed (Brassica napus L.) for yield and yield attributes. Sarbad Journal of Agriculture, 37(1): 104-109.
DOI | httt://dx.doi.org/10.17582/journal.sja/2021/37.1.104.109
Keywords | Diallel fashion, Morphological, Yield-related traits, Combining ability, Heritability, Gene action

\section{Introduction}

$B$ rassica napus L. is a particular canola cultivar, having a bright yellow flowering of the family Cruciferae, cultivated widely for the rich source of oil. Rapeseed and mustard are two main key groups used to categorize the species of Brassica genus. Brassica rapa L., B. napus L., and B. nappobrassica L., are generally considered as rapeseed (Zhou et al., 2006). Brassica genus had vast economic importance on the base of oilseed crop throughout the world. In the South East of Asia, it was cultivated since 4000
BC (Snowdown et al., 2007). Brassica species are believed to be originated at Mediterranean, Canada and Europe (Rakow, 2004). In Brassica species the most promising specie is Brassica napus L., an amphidiploid having AACC genome $(2 n=38)$, is one of the most promising brassica specie developed by a cross between $B$. rapa L. ( $2 \mathrm{n}=20$, AA genome) and $B$. oleracea L. (2n=18, CC genome) (Iniguez and Federico, 2010).

In Pakistan, the total area of 24.7 thousand hectares was planted by rapeseed and mustard with a per 
hectare production of $939.27 \mathrm{~kg}$ (FAO Statistics, 2016). Brassica napus L., was generally grown for seed and oil purpose. The limited cultivation of rapeseed in Khyber Pakhtunkhwa and some areas of Punjab province are the main reasons for low production (Saleem et al., 2015). The factors responsible for this, lower than the world average, production scarcity of quality varietal seeds, limitation of irrigational water, unavailability of modern technologies, unexpected weather conditions, climate change and growing population. It is need of the time to develop high yielding cultivars especially in $B$. napus L., to fill up the gap of local requirements and ultimately reduce the import of edible oil (Ghosh and Gulati, 2002).

Diallel crosses were analyzed in theoretical practices utilizing a biometrical program specified for combining ability (Griffing, 1956). Combing ability helped us to determine the performance of individual genotypes by observing its combination in offsprings (Sincik et al., 2015). Based on general and specific combining ability effects, it could be determined whether an individual be involved or not in advanced breeding practices (Zhou et al., 2006). Combining ability provides information about the desirable genotype, nature and magnitude of gene action. The GCA represents the additive type of gene action, while the SCA represents the non-additive gene action (Malik et al., 2004; Akbar et al., 2008). The genetic diversity among the genotypes is evident from combining ability, gene action and heritability studies, as they all are linked together, thus used in the selection procedure of superior genotypes. Narrow sense heritability is generally related to the GCA and additive gene action, whereas SCA and nonadditive gene action is correlated with broad-sense heritability (Marwede et al., 2004). The existence of genetic variability can be calculated using heritability estimates, thus helped in bringing improvement in the crop performance (Khan et al., 2006).

Keeping in view the significance of edible oil and its scarcity in the country, the present research was designed to determine the effect of combining ability, heritability and gene action on the yield performance of different diallel crosses in B. napus developed for high yielding traits.

\section{Materials and Methods}

The field experiments related to oil crop research were carried out at the Bacha Khan Agriculture Research Farm (BARF) Charsadda during 20172019. The experimental material consisted of five rapeseed varieties. Parental material sowed under field condition during December, 2017. During February, 2018 at the time of flowering hybridization through emasculation and controlled pollination was carried out in $5 \times 5$ diallel fashion. Sowing of the investigational material included of $\mathrm{F} 1$ hybrid seed resulting from intercrosses among these five varieties, including self, direct and reciprocals were carried out in randomized complete block design (RCBD) having two replications during 2018-2019 sowing season at BARF Charsadda. Each entry comprised of a single row of $1 \mathrm{~m}$ length. Rows were kept at 60 $\mathrm{cm}$ apart whereas the standard distance of $25 \mathrm{~cm}$ was maintained by thinning out additional plants at an early four-leaf stage in each experimental plot. Standard agricultural practices were adopted during the vegetative and reproductive phases. At maturity data was collected for days to $50 \%$ flowering, days to $50 \%$ maturity, plant height, primary branches plant ${ }^{-1}$, pods plant ${ }^{-1}$, pod length, seed pod $^{-1}$, seed yield plant ${ }^{-1}$, total yield and 1000 seed weight. Traits revealing significant differences were analyzed according to Griffing (1956) method (fixed effect) for combining ability analysis; heritability estimates and gene action.

$$
\begin{aligned}
& \text { Statistical analysis } \\
& \begin{array}{c}
\text { Yij }=m+g_{\mathrm{i}}+\mathrm{g}_{\mathrm{j}}+\mathrm{s}_{\mathrm{ij}}+\mathrm{r}_{\mathrm{ij}}+1 / \mathrm{bc} \Sigma \Sigma \mathrm{e}_{\mathrm{ijkl}} \\
\mathrm{Yij}=\text { mean of } \mathrm{i} \times \mathrm{j} \text { th genotype over } \mathrm{k} \text { and } 1 \\
\mathrm{~g}_{\mathrm{i}}=\mathrm{GCA} \text { of } \mathrm{i} \text { th parent } \\
\mathrm{g}_{\mathrm{j}}=\mathrm{GCA} \text { effect of } \mathrm{j} \text { th parent } \\
\quad \mathrm{s}_{\mathrm{ij}}=\text { SCA effect } \\
1 / \mathrm{bc} \Sigma \Sigma \mathrm{e}_{\mathrm{ij} \mathrm{kl}}=\text { mean error effect }
\end{array}
\end{aligned}
$$

Estimation of heritability was studied according to Weber and Moorthy (1952).

\section{Results and Discussion}

The average performance of various genotypes and their crosses revealed significant and highly significant differences for different traits, i.e., pods plant $^{-1}$ (Ali et al., 2015), pod length (Sincik et al., 2011), seed pod $^{-1}$ (Ali et al., 2015), total yield (Ali et al., 2015) and 1000 seed weight (Junaid et al., 2014) (Table 1). Mean value of pods plant ${ }^{-1}$ revealed that parental genotype P1-801 attained the maximum value of 192, while genotype 2702 revealed minimum mean value 157 pods in each plant, the maximum 
value of 222 pods plant ${ }^{-1}$ among cross combinations were exhibited by $2702 \times$ DUNCLED, while P1-801 $\times$ P1-119 attained minimum 172 pods plant ${ }^{-1}$. It is cleared from Table 2 that maximum and minimum mean pod length among parental lines were evident for genotype $2702(7.5 \mathrm{~cm})$ and genotype P1-801 (6.4), respectively whereas maximum and minimum mean value among cross combination varied between $7.1 \mathrm{~cm}$ and $5.9 \mathrm{~cm}$ attained by P1-119×2702 (F1) and $2722 \times \mathrm{P} 1-801(\mathrm{~F} 1)$. Parental genotype P1-119 and 2722 attained maximum (26.1) and minimum (24.6) values, respectively when seeds pod ${ }^{-1}$ was taken into consideration, however for cross combinations, the maximum number of 27.4 seed pod $^{-1}$ were reported for $2702 \times 2722$, while the minimum value for seeds pod $^{-1}$ (14) was recorded in P1-801×2722 (F1). Maximum mean total yield for parental and F1 genotypes was attained by $2722(109 \mathrm{~g})$ and P1-119×2722 (114g) while minimum mean total yield was observed for parental genotype DUNCLED $(82.9 \mathrm{~g})$ and DUNCLED $\times 27012$ (74 g), respectively. Parental genotypes 2702 and $\mathrm{P} 1-119$ revealed maximum (6.1g) and minimum (4.0g) mean values for 1000 seed weight, respectively. Whereas P1-801×P1-119 (F1) and P1-119×P1-801 (F1) attained highest (6.4 $\mathrm{g})$ and lowest $(4.09 \mathrm{~g})$ seed weight among the cross combinations, respectively. Pod length, pods plant ${ }^{-1}$, Seeds pod ${ }^{-1}$ and seed yield plant ${ }^{-1}$ are the major yield contributing traits.

Table 1: Analysis of variance for combining ability in Brassica napus. $L$.

$\begin{array}{lllllll}\text { SOV } & \text { D.F PPP } & \begin{array}{l}\text { PL } \\ (\mathbf{c m})\end{array} & \text { SPP } & \text { TY (g) } & \begin{array}{l}\mathbf{1 0 0 0} \\ \text { SW (g) }\end{array} \\ \text { Reps } & 1 & 1551.2 & 8.703 & 14.15 & 264.04 & 1.613 \\ \text { Crosses } & 24 & 512.9^{*} & 0.319^{*} & 16.62^{*} & 235.24^{* *} & 0.882^{* *} \\ \text { Error } & 24 & 220.3 & 0.160 & 6.61 & 61.41 & 0.31 \\ \text { CV (\%) } & \ldots & 7.9 & 6 & 11.2 & 9 & 10.5\end{array}$

*** probability levels at 0.05 and 0.01 , respectively.

Variation among genotypes for combing ability analysis, to identify the best-performing parents for yield attributes, was carried out for those traits which showed significant differences. The results for general combining ability were shown in Table 3. General combining ability is useful to figure out a good combiner, which ultimately helps in developing cultivars having wider adaptability and resistance. Now a days the breeders are struggling to produce the short duration genotype having high yield and quality through combining ability studies. It was revealed from Table 3 that pods plant $^{-1}$, pod length, seed pod $^{-1}$, total yield and 1000 grain weight exhibited significant differences among the genotypes studied. Parental genotype 2722 (10.1) exhibited good general combining ability for pods plants ${ }^{-1}$ performance among the genotypes studied, whereas parental genotype P1-119 (-6.45) revealed poor combining ability for the said trait. The range of GCA effects for pod length varied between 0.22 (2702) and -0.25 (2722). The analyzed data for seeds pod $^{-1}$ revealed that parental genotype 2702 (1.62) was significantly different for general combining ability compared to other parental genotypes hence proved to be a finest general combiner for this trait followed by P1-119 (0.15), the rest of genotypes showed relatively less general combining ability. Total yield, the most looked-for trait, revealed that the genotypes 2702 (5.76) and DUNCLED (-5.91) bare significant differences and were found to be best and worst general combiners for this trait. The better combining ability performance of parental genotype 2702 (0.37) for 1000 seed weight was evident from Table 3. On the other hand, parental genotype P1-119 (-0.51) revealed a significantly low general combining ability was. The contradiction in the conclusions must be due to diversified genotypes and environment. Highly significant GCA were reported with desirable GCA effects for relevant traits among parents of B. napus L. (Gul et al., 2018; Suchindra and Singh, 2006; Sincik et al., 2015).

The best cross combinations were identified by subjecting the significantly different traits to analysis for specific combining ability (Table 4). High significant and superior specific combining ability for pods plant ${ }^{-1}$ was evident for a cross combination of $2702 \times$ DUNCLED (34.9), whereas DUNCLED $\times$ P1-119 (-7.63) revealed poor specific combining ability for this trait. Similarly, P1$801 \times \mathrm{P} 1-119$ cross combination revealed the maximum value of SCA (0.46) for pod length, likely followed by $2702 \times \mathrm{P} 1-119(-0.05)$, besides $\mathrm{P} 1-119 \times 2722$ determined the minimum SCA (-0.44) for pod length. Variance due to SCA for seeds pod ${ }^{-1}$ revealed that cross combination $2702 \times$ DUNCLED (1.89) attained maximum value followed by $\mathrm{P} 1-801 \times \mathrm{P} 1-119$ (1.71), similarly significantly different and minimum SCA value was observed for DUNLED $\times \mathrm{P} 1-119(-7.14)$. When total yield was taken into consideration, it was cleared from SCA values that a cross combination 
of genotype $2702 \times 2722$ attained significantly high value (18.7) for this trait followed by $2702 \times \mathrm{P} 1-119$ (10), whereas minimum significant different SCA values were evident for a cross between genotype $2702 \times$ DUNCLED and $2702 \times \mathrm{P} 1-801(-10.8)$. The analysis of data for 1000 seed weight revealed the positively high value of variance due to SCA for P1-119×2722 (0.51), whereas minimum negative SCA (-0.68) value was reported for P1-801 $\times \mathrm{P} 1-119$. Yadava et al.(2012) also elaborated significant negative results for specific combining ability. It is evident from the above discussion that the performance of those crosses where genotype 2702 was used as seed setter or donor parent was better as compared to others. This affirmed our general combing ability results which revealed genotype 2702 as a good general combiner.

Table 2: Mean performance for pods plant ${ }^{-1}$, pod length (cm), Seeds pod ${ }^{-1}(\mathrm{~g})$, total yield (g) and 1000 seed weight (g) of five parents and diallel crosses.

\begin{tabular}{|c|c|c|c|c|c|c|}
\hline $\begin{array}{l}\text { S. } \\
\text { No }\end{array}$ & Parents & PPP & $\begin{array}{l}\text { PL } \\
\text { (cm) }\end{array}$ & SPP & $\begin{array}{l}\text { TY } \\
\text { (g) }\end{array}$ & $\begin{array}{l}1000 \\
\text { SW (g) }\end{array}$ \\
\hline 1 & 2702 & 156.6 & 7.5 & 25.3 & 93.3 & 6.1 \\
\hline 2 & DUNCLED & 158.8 & 7.1 & 24.7 & 82.9 & 5.2 \\
\hline 3 & P1-801 & 192 & 6.4 & 26 & 84.1 & 5.9 \\
\hline 4 & P1-119 & 179.9 & 6.7 & 26.1 & 96.0 & 4.0 \\
\hline 5 & 2722 & 178.1 & 6.6 & 24.6 & 109 & 4.9 \\
\hline 6 & $2702 \times$ DUNCLED & 222 & 6.7 & 24.5 & 74.4 & 5.4 \\
\hline 7 & $2702 \times P 1-801$ & 186.3 & 7 & 21.9 & 75.2 & 5.7 \\
\hline 8 & $2702 \times P 1-119$ & 216.9 & 7 & 23 & 76.4 & 5.6 \\
\hline 9 & $2702 \times 2722$ & 213.0 & 6.8 & 27.4 & 80.8 & 5.6 \\
\hline 10 & DUNCLED×2702 & 200.3 & 6.5 & 24.6 & 74.0 & 5.2 \\
\hline 11 & DUNCLED×P1-801 & 187.6 & 6.5 & 23.4 & 78.0 & 5.6 \\
\hline 12 & DUNCLED $\times P 1-119$ & 184.1 & 6.5 & 21.6 & 87.1 & 5.6 \\
\hline 13 & DUNCLED×2722 & 178.9 & 7 & 20.43 & 83.0 & 5.6 \\
\hline 14 & P1-801×2702 & 185.5 & 6.4 & 24.6 & 93.0 & 5.8 \\
\hline 15 & P1-801×DUNCLED & 178.5 & 6.6 & 17.5 & 87.4 & 5.7 \\
\hline 16 & $\mathrm{P} 1-801 \times \mathrm{P} 1-119$ & 172 & 6.8 & 25.3 & 99.6 & 6.4 \\
\hline 17 & P1-801×2722 & 178.1 & 6.2 & 14 & 79.7 & 6.2 \\
\hline 18 & P1-119×2702 & 184.5 & 7.1 & 23.7 & 79.8 & 4.9 \\
\hline 19 & P1-119×DUNCLED & 175.8 & 7 & 24.3 & 78.0 & 4.6 \\
\hline 20 & $\mathrm{P} 1-119 \times \mathrm{P} 1-801$ & 181.5 & 6.2 & 21.55 & 104.9 & 4.1 \\
\hline 21 & $\mathrm{P} 1-119 \times 2722$ & 194.7 & 6.2 & 21.6 & 114 & 4.1 \\
\hline 22 & $2722 \times 2702$ & 200.9 & 6.1 & 20.7 & 79.0 & 4.7 \\
\hline 23 & $2722 \times$ DUNCLED & 196.6 & 6 & 21 & 85.2 & 4.7 \\
\hline 24 & $2722 \times P 1-801$ & 196.0 & 5.9 & 23.5 & 86.5 & 4.8 \\
\hline 25 & $2722 \times \mathrm{P} 1-119$ & 205.2 & 6.9 & 23.9 & 87.5 & 4.8 \\
\hline
\end{tabular}

Table 3: General combining ability (GCA) effects of

parents for different yield related traits in Brassica napus.
$\begin{array}{llllll}\text { L. } \\ \text { Parents } & \text { PPP } & \text { PL (cm) } & \text { SPP } & \text { TY (g) } & \mathbf{1 0 0 0 ~ S W ~ ( g ) ~} \\ 2702 & -5.46 & 0.22 & 1.62^{*} & 5.76^{*} & 0.37 \\ \text { DUNCLED } & 4.23 & -0.03 & -1.35 & -5.91^{*} & 0.06 \\ \text { P1-801 } & -2.44 & 0.04 & -0.50 & -2.29 & 0.30 \\ \text { P1-119 } & -6.45 & 0.02 & 0.15 & -1.48 & -0.51^{*} \\ 2722 & 10.12^{*} & -0.25 & 0.08 & 3.91 & -0.21\end{array}$

* and ** probability levels at 0.05 and 0.01 , respectively.

Table 4: Specific combining ability effects (SCA) of the crosses for different yield related traits in Brassica napus. $L$.

\begin{tabular}{|c|c|c|c|c|c|}
\hline Crosses & PPP & $\begin{array}{l}\text { PL } \\
(\mathbf{c m})\end{array}$ & SPP & TY $(g)$ & $\begin{array}{l}1000 \\
\text { SW (g) }\end{array}$ \\
\hline 2702×DUNCLED & $34.98^{* *}$ & -0.08 & 1.89 & $-10.8^{*}$ & -0.31 \\
\hline $2702 \times \mathrm{P} 1-801$ & 7.56 & -0.41 & -0.06 & $-10.8^{*}$ & 0.08 \\
\hline $2702 \times \mathrm{P} 1-119$ & -3.73 & -0.05 & 1.19 & 10.0 & 0.04 \\
\hline $2702 \times 2722$ & 2.05 & -0.41 & -2.44 & $18.7^{* *}$ & -0.53 \\
\hline DUNCLED×P1-801 & -5.68 & -0.16 & 1.11 & 9.9 & 0.31 \\
\hline DUNCLED $\times P 1-119$ & -7.63 & -0.45 & $-7.14^{* *}$ & 1.8 & 0.03 \\
\hline DUNCLED×2722 & -1.45 & -0.23 & -0.37 & -4.4 & -0.17 \\
\hline $\mathrm{P} 1-801 \times \mathrm{P} 1-119$ & 5.45 & 0.46 & 1.71 & -1.8 & -0.68 \\
\hline P1-801×2722 & 0.98 & -0.40 & -0.92 & -1.8 & -0.33 \\
\hline $\mathrm{P} 1-119 \times 2722$ & 4.39 & -0.49 & 0.93 & -1.3 & 0.51 \\
\hline
\end{tabular}

${ }^{*}$ and ${ }^{* * *}$ probability levels at 0.05 and 0.01 , respectively.

The heritability analysis and gene action were shown in Table 5. The higher value of phenotypic variance than genetic variance indicated that the environment has a profound effect on the phenotypic expression of these traits. Broad sense heritability and non-additive type of gene action were observed for the traits under study (PPP, PL, SPP, TY and 1000 SW). These findings are in agreement with Khan et al. (2013) and Aytac and Kinaci (2009) who reported high broadsense heritability. Contrary to our finding Afrin et al. (2012), Zare and Sharafzadeh (2012) and Rameeh (2015) reported narrow sense heritability in B. napus L.

Table 5: Heritability estimates and gene action of different yield related traits.

$\begin{array}{llllll}\text { Attributes } & \mathbf{h}^{2} \mathbf{B} & \mathbf{h}^{2} \mathbf{N} & \boldsymbol{\sigma}^{2} \mathbf{A} & \boldsymbol{\sigma}^{2} \mathbf{D} & \boldsymbol{\sigma}^{2} \mathbf{P} \\ \text { PPP } & 0.14 & 0.14 & 58.8 & 0 & 412.5 \\ \text { PL } & 0.30 & 0.04 & 0.01 & 0.06 & 0.24 \\ \text { SPP } & 0.14 & 0.12 & 1.53 & 0.31 & 12.5 \\ \text { TY } & 0.56 & 0.28 & 45.3 & 46.7 & 162.1 \\ \text { 1000 SW } & 0.27 & 0.27 & 0.20 & 0 & 0.75\end{array}$


Conclusions and Recommendations

Relatively higher values for variances due to SCA than GCA confirmed the occurrence of Broad sense heritability, whereas gene action for the traits under study was found to be of non-additive type. Genotype 2702 performed better for pod length, seed pod $^{-1}$, total yield and 1000 seed weight and was identified as a best general combiner. Similarly, among a cross combination of parental genotypes, $2702 \times \mathrm{P} 1-119$ attained prominent SCA for all the traits except pods plant ${ }^{-1}$ and showed better average performance. Thus it could be evident from the above combining ability and genetic studies that genotypes 2702 and P1-119 could be further exploited for future breeding programs and could be securely used for the betterment of related traits in Rapeseed canola.

\section{Novelty Statement}

Identify the variation in the existing germplasm to get promising lines for future breeding program of the department.

\section{Author's Contribution}

Muhammad Ali Shah: Data analysis and write up

Faiz ur Rehman: Helped in data collection..

Abbas Mehmood: Performed field work.

Fareed Ullah: Field work.

Sayed Irfan Shah: Helped in data entry and compiling.

Syed Majid Rasheed: Supervised the research.

\section{Conflict of interest}

The authors have declared no conflict of interest.

\section{References}

Afrin, K.S., F. Mahmud and M.A. Rahim. 2012. Genetic divergence in advanced lines of oilseed Rape (Brassica napus L.). Agric. Conspec. Sci., 77(2): 81-85.

Akbar,M.,B.M.Tahira, Atta and M. Hussain.2008. Combining ability studies in rapeseed (Brassica napus L.). Int. J. Agric. Biol., 10: 205-208.

Ali, A., N.U. Khan, S. Ali, F. Ullah, S. Gul, M. Saeed and K. Naveed. 2015. Combining ability studies for quantitative traits in $B$. juncea. J. Anim. Plant. Sci., 25(2): 495-501.

Ali, M., R. Uddin, M. Sajid, Q.U. Bacha, A.U.
Rahman and S.A. Khan. 2014. Combining ability and heritability for yield contributing traits in F1 population Brassica napus L. AmeriEurasian. J. Agric. Envron. Sci., 14(6): 509-515.

Aytac, Z. and G. Kinaci. 2009. Genetic variability and association studies of some quantitative characters in winter rapeseed (Brassica napus L.). Afric. J. Biotech., 8(15): 3547-3554.

FAO Statistics. 2016. Food and Agricultural Organization (FAO), United Nation. http:// www.fao.org/faostat/en/\#home.

Ghosh, S.K. and S.C. Gulati. 2002. Parental diversity to realize maximum heterosis in Indian mustard. Ind. J. Gen., 62(1): 25-28.

Griffing, B., 1956. Concept of general and specific combining ability in relation to diallel system. Aust. J. Biol. Sci., 9: 483-493. https://doi. org/10.1071/BI9560463

Gul, S., R. Uddin, N.U. Khan, M. Arif, R. Gohar and M. Zakaria. 2018. Inheritance studies through combining ability for morphological and yield traits in F1 populations of Brassica napus L. J. Anim. Plant Sci., 28(4): 1094-1102.

Iniguez, F.L., and M.L. Federico. 2010. The Genetics of Brassica napus. Book. Series, 9: 291-322. https://doi.org/10.1007/978-14419-7118-0_10

Junaid, M., Raziuddin, M. Kanwal, M. Umair, S. Ahmed, N. Ahmed, A.A. Alizai and N. Bano. 2014. Heritability (BS) and selection response estimates for yield and yield related traits in Brassica napus L. J. Mat. Environ. Sci., 5(4): 1107-1110.

Khan, F.A., S. Ali, A. Shakeel, A. Saeed and G. Abbas. 2006. Genetic variability and genetic advance analysis for some morphological traits in (Brassica napus L.). J. Agric. Res., 44(2): 8388.

Khan, F.U., R. Uddin, I.A. Khalil, I.H. Khalil and I. Ullah. 2013. Heritability and genetic potential of Brassica napus genotype for yield and yield components. Am. Eur. J. Agric, Environ. Sci., 13(6): 802-806.

Malik, S.I., H.N. Malik, N.M. Minhas and M. Munir. 2004. General and specific combining ability studies in maize. Int. J. Agric. Biol., 6: 856-859.

Marwede, V., A. Schierholt, C. Mollers and H.C. Becker. 2004. Genotype $\times$ environment interactions and heritability of tocopherol contents in Canola. J. Crop. Sci., 44: 728-731. 
https://doi.org/10.2135/cropsci2004.7280

Rakow, G., 2004. Species origin and economic importance of brassica. Biotechnol. Agric. For., Brassicas. Springer-Verlag Berlin Heidelberg, Vol. 54. https://doi.org/10.1007/978-3-66206164-0_1

Rameeh, V., 2015. Heritability, Genetic variability and correlation analysis of some important agronomic traits in rapeseed advance lines. Cercetari Agron. Moldova, 48(4): 71-80. https://doi.org/10.1515/cerce-2015-0054

Saleem, Z., J. Iqbal, S.G. Khattak, N. Muhammad, Z. Iqbal and M. Khan. 2015. Evaluation of advanced rapeseed (B. napus L.) lines under rainfed conditions of Khyber Pakhtunkhwa. J. Agric. Res., 53(4): 535-540.

Sincik, M., E. Sozen, K. Falk, A. Goksoy and E. Acikgoz. 2011. Heterosis and combining ability in a diallel cross of turnip rape genotypes. Turk. J. Field. Crops, 19(2): 219-224. https://doi. org/10.17557/tjfc. 27610

Suchindra, B. and J.N. Singh. 2006. Combining ability analysis of seed yield and oil content in
Brassica napus L. J. New. Bot., 33: 173-179.

Weber, C.R. and B.R. Moorthy. 1952. Heritable and nonheritable relationships and variability of oil content and agronomic characteristics in F2 generation of soybean crosses. Agro. J., 44: 202-209. https://doi.org/10.2134/agronj1952. 00021962004400040010x

Yadava, D.K., N. Singh, S. Vasudev, R. Singh, S. Singh, S.C. Giri, V.K. Dwivedi and K.V.Prabhu. 2012. Combining ability and heterobeltiosis for yield and yield-contributing traits in Indian Mustard (Brassica juncea). Ind. J. Agric. Sci., 82(7): 563-567.

Zare, M.S. and S. Sharafzadeh. 2012. Genetic variability of some rapeseed (Brassica napus L.) cultivars in southern Iran. Afri. J. Agric. Res., 2: 224-229.

Zhou, W.J., G.Q. Zhang, S. Tuvesson, C. Dayteg and B. Gertsson. 2006. Genetic survey of Chinese and Swedish oilseed rape (B. napus L.) by simple sequence repeats (SSRs). Gen. Resour. Crop. Eviron., 53(3): 443-447. https:// doi.org/10.1007/s10722-004-7862-6 